\title{
Investigation Group Learning Models On Social Sciences Learning
}

\author{
W A U Wardoyo ${ }^{1}, \mathrm{~J} \mathrm{M} \mathrm{Sumilat}^{2}$ \\ ${ }^{1}$ Student, Universitas Negeri Manado, Indonesia \\ ${ }^{2}$ Universitas Negeri Manado, Indonesia \\ corresponding author: julianasumilat@unima.ac.id
}

\begin{abstract}
The purpose of this study is to improve learning outcomes of natural resources material in social sciences subjects. This study uses a classroom action research method with four stages, namely planning, action, observation, and reflection. Data collection on learning outcomes is obtained through tests. Data analysis was done by calculating the percentage of completeness of learning, and research was said to be successful if the completeness of learning outcomes was $85 \%$. The results of the study in the first cycle showed that Social sciences learning outcomes reached $68.85 \%$ and after the implementation of improved learning in the second cycle learning outcomes increased to $88.84 \%$. This study concluded that the application of the investigation group model can improve student learning outcomes in social sciences learning.
\end{abstract}

Keywords: Group Investigation Learning Model, Social sciences Learning Outcomes

\section{Introduction}

Education is the process of developing one's skills in the form of attitudes and behaviors that apply in their society. Social processes where a person is influenced by a guided environment (especially in school) so that he can achieve social skills and develop his personality. With the enactment of Law Number 20 of 2003 concerning the National Education System, a person who works in the world of education, both formal, non-formal and informal, must have special abilities in the field of education. In general, the teacher must be competent in his field. Therefore, to find out how the competence of an education expert, in which are teachers, principals, and school administrators, in this theory study will be discussed about teacher competency, principal performance, teacher performance, supervision, educative, and action hypothesis.

Achieving the functions and objectives of social sciences subjects in elementary school is important to be able to be carried out by the teacher in the teaching learning process by applying the learning principles of the function and purpose as explained in the role of learning social sciences of Elementary School in 1999 as follows: "Elementary Social sciences study material organized starting from the part of the lesson that is close and simple around the child to a broader and more complex one. The goal is a measure of learning experience that must be achieved by 
students after learning one or several subjects. In the implementation of teaching and learning activities teachers both physically, mentally (thoughts and feelings), and social and in accordance with the level of development of elementary schools.

However, because social sciences learning materials have a wide and wide scope and the demands of the curriculum are loaded with content that must be delivered to students with limited time locations, the teacher has difficulty in presenting social sciences teaching materials well, interestingly, and challenging students' learning interests, in the end Social sciences learning conducted in Class IV of TOMOHON GMIM VIII Elementary School is by doing learning to be able to pursue the target. The demands of the curriculum by relying on learning materials from available Grade IV social sciences source books, the teaching method so far is not suitable because the teacher gives lectures so that it does not involve students in social sciences teaching and learning activities.

Based on observations in SD GMIM VIII Tomohon class IV, Social sciences Subject, with the number of students 13 people only 5 students who completed the learning outcomes and 10 students who did not complete the learning outcomes. This is because the way of teaching does not involve students and students do not understand how to work in groups and interact with other students. To overcome this problem, so many ways that have been taken include the application of approaches and learning models in the teaching and learning process. With the problems described above, one of the teaching and learning models that are considered to be able to involve active students in social sciences teaching and learning activities includes group learning, Group Investigation. Because by involving students actively in social sciences teaching and learning activities will be felt memorable and meaningful as well as can encourage students to learn more, through learning in groups students can learn to be more creative in solving problems in mutual cooperation hand in hand in achieving goals. Based on the background that has been stated, this problem can be formulated as follows: How is the Application of Group Investigation Model to Improve Social sciences Learning Outcomes of Grade IV Elementary Students? The purpose of this study was to improve social sciences learning outcomes through the application of the Group Investigation learning model for fourth grade elementary school students.

Learning Model is a plan or pattern that organizes learning in class and shows how to use learning material [1]. Investigation Group is one form of cooperative learning model that emphasizes the participation and activities of students to search for their own material (information) lessons to be learned through available materials, for example from textbooks or students can search the internet. Students are involved since planning, both in determining topics and ways to study them through investigation. This type requires students to have good skills in communication and in group process skills. The Group Investigation model can train students to foster the ability to think independently. Active involvement of students can be seen from the first stage to the final stage of learning [2]. According to Trianto group investigation is a type of group learning that involves students in 
planning both of the topics being studied and how their investigation progresses [3]. Joyce and Weil explain that group investigation is a type of group learning that has a basic concept of giving and raising a problem to stimulate students to react and solve the problem [4].

Based on the experts' opinions about the Group Investigation learning model, it was concluded that the Group Investigation Model is a group learning model that emphasizes students to be active in learning and train students to have the ability to communicate and express their opinions.

\section{Method}

The research method is carried out in the form of classroom action research (CAR) which refers to the research design proposed by Kemmis and Taggart with the following stages: Planning, Implementation / action, Observation / observation and Reflection [5]. Subjects in this class action research were fourth grade students of SD GMIM VIII Tomohon, totaling 13 students consisting of 5 male students 8 female students.

Data collection techniques in this study are through learning outcomes tests. The data that has been obtained is then analyzed to determine the extent of students' mastery of the material presented. In this case the researcher uses descriptive statistical analysis in the form of the percentage of learning completeness

\section{Results and discussion}

\section{Results}

This research was conducted in the even semester of the academic year 20152016 in the fourth grade of SD GMIM VIII Tomohon, with 13 students consisting of 8 female students, 5 male students, and researchers acting directly as classroom teachers while homeroom teachers as obsevers. Research using the Group Investigation learning model carried out at SD GMIM VIII Tomohon, the first cycle was held on Friday April 252016 and cycle II on May 3, 2016. Implementation of the actions of cycle I and cycle II was carried out according to PTK stages namely planning, action, observation and reflection.

Results of cycle I

Learning outcomes obtained in the application of the investigative group learning model in social learning for fourth grade students of SD GMIM VIII Tomohon in sycle I are presented in the table 1. 
Table 1. Results of cycle I

\begin{tabular}{|c|c|c|c|c|c|c|c|c|}
\hline \multirow[t]{2}{*}{ No } & \multirow{2}{*}{$\begin{array}{l}\text { Student } \\
\text { Name }\end{array}$} & \multicolumn{6}{|c|}{ Question number and Question weight } & \multirow[t]{2}{*}{ Value } \\
\hline & & $1 / 10$ & $2 / 10$ & $3 / 10$ & $4 / 20$ & $5 / 25$ & $6 / 25$ & \\
\hline 1 & AK & 10 & 10 & - & 15 & 25 & 25 & 85 \\
\hline 2 & AM & - & 10 & - & 10 & 15 & 20 & 55 \\
\hline 3 & $\mathrm{AP}$ & 10 & 10 & 10 & 20 & 15 & 20 & 85 \\
\hline 4 & CT & 10 & 10 & 10 & 20 & - & - & 50 \\
\hline 5 & KU & 10 & 10 & 10 & 20 & 10 & 25 & 85 \\
\hline 6 & IU & 10 & - & - & - & 25 & - & 35 \\
\hline 7 & MP & 10 & 10 & 10 & 20 & - & - & 50 \\
\hline 8 & MM & 10 & 10 & 10 & 20 & - & - & 50 \\
\hline 9 & HM & 10 & 10 & - & 20 & 25 & 20 & 85 \\
\hline 10 & SW & 10 & - & 10 & 20 & 20 & 25 & 85 \\
\hline 11 & TR & - & 10 & - & 15 & 15 & 20 & 60 \\
\hline 12 & ZR & 10 & 10 & 10 & 20 & 10 & 25 & 85 \\
\hline \multirow[t]{4}{*}{13} & KS & 10 & 10 & 10 & 20 & 15 & 20 & 85 \\
\hline & \multicolumn{7}{|c|}{ Total Score } & 895 \\
\hline & \multicolumn{7}{|c|}{ Maximum Total Score } & 1300 \\
\hline & $\begin{array}{l}\text { Val } \\
\text { 10: } \\
\text { 20: } \\
\text { 25: }\end{array}$ & $\begin{array}{l}\text { Crite } \\
\text { sy } \\
\text { edium } \\
\text { fficult }\end{array}$ & & & & & & \\
\hline
\end{tabular}

So the completeness of the first cycle is

Formula:

$\mathrm{KB}=\frac{T}{T t} \times 100 \%$

$\mathrm{T}=$ Total score

$\mathrm{Tt}=$ maximum total score

$\mathrm{KB}=\frac{85}{1300} \times 100 \%$

$\mathrm{KB}=68.85 \%$

From the results of the first cycle, it can be seen that the results obtained in the first cycle did not reach classical learning completeness by $85 \%$, the achievement of learning outcomes in the first cycle only reached $68.85 \%$. therefore it is necessary to continue the action in the second cycle.

Results of cycle II

Learning outcomes obtained in the application of the investigative group learning model in social learning for fourth grade students of SD GMIM VIII Tomohon in sycle II are presented in the table 2. 
Table 2. Results of cycle II

\begin{tabular}{|c|c|c|c|c|c|c|c|c|}
\hline \multirow[t]{2}{*}{ No } & \multirow{2}{*}{$\begin{array}{l}\text { Student } \\
\text { Name }\end{array}$} & \multicolumn{6}{|c|}{ Question number and Question weight } & \multirow[t]{2}{*}{ Value } \\
\hline & & $1 / 10$ & $2 / 10$ & $3 / 10$ & $4 / 20$ & $5 / 25$ & $6 / 25$ & \\
\hline 1 & $\mathrm{AK}$ & 10 & 10 & 10 & 20 & 15 & 20 & 85 \\
\hline 2 & AM & 10 & 10 & 10 & 20 & 15 & 20 & 85 \\
\hline 3 & $\mathrm{AP}$ & 10 & 10 & 10 & 15 & 20 & 20 & 85 \\
\hline 4 & CT & 10 & 10 & 10 & 20 & 15 & 20 & 85 \\
\hline 5 & KU & 10 & 10 & 10 & 20 & 15 & 25 & 90 \\
\hline 6 & IU & 10 & 10 & 10 & 20 & 15 & 20 & 85 \\
\hline 7 & MP & 10 & 10 & 10 & 20 & 25 & 15 & 90 \\
\hline 8 & MM & 10 & 10 & 10 & - & 25 & 25 & 80 \\
\hline 9 & $\mathrm{HM}$ & 10 & 10 & 10 & - & 25 & 25 & 80 \\
\hline 10 & SW & - & 10 & 10 & 20 & 25 & 25 & 90 \\
\hline 11 & TR & 10 & 10 & 10 & 20 & 25 & 25 & 100 \\
\hline 12 & $\overline{Z R}$ & 10 & 10 & 10 & 20 & 25 & 25 & 100 \\
\hline \multirow[t]{4}{*}{13} & $\mathrm{KS}$ & 10 & 10 & 10 & 20 & 25 & 25 & 100 \\
\hline & \multirow{2}{*}{\multicolumn{7}{|c|}{$\begin{array}{r}\text { Total Score } \\
\text { Maximum Total Score }\end{array}$}} & 1155 \\
\hline & & & & & & & & 1300 \\
\hline & \multicolumn{7}{|c|}{$\begin{array}{l}\text { Value Criteria } \\
\text { 10: Easy } \\
\text { 20: Medium } \\
\text { 25: Difficult }\end{array}$} & \\
\hline
\end{tabular}

So the completeness of the second cycle is

Formula:

$$
\begin{aligned}
& \mathrm{KB}=\frac{T}{T t} \times 100 \% ; \\
& \mathrm{T}=\text { Total score } \\
& \mathrm{Tt}=\text { maximum total score } \\
& \mathrm{KB}=\frac{1155}{1300} \times 100 \% \\
& \mathrm{~KB}=88.84 \%
\end{aligned}
$$

From the data in table 2, it can be seen that student learning outcomes in the second cycle have reached and exceeded the mastery of learning in a classical manner which is $85 \%$. Achievement of learning outcomes in the second cycle was $88.84 \%$. Learning outcomes achieved in this second cycle show that the success criteria for the research have been achieved, thus the actions taken in the second cycle are declared successful and do not need to be continued in the next cycle.

\section{Discussion}

The success of teachers in the learning process can be assessed based on the achievement of planned learning goals. The purpose of social sciences learning in elementary schools is that students recognize concepts related to the lives of people and their environment. Which means that social sciences education emphasizes giving direct experience to find out and act so that students are able to explore and 
understand the natural resources that exist in the territory of Indonesia. However, the reality of teaching and learning activities is that there are still many students who have learning difficulties and have no motivation to learn, there are also students who like to play, so in social sciences learning needs to apply a Group Investigation learning model so students can be active in the learning process.

Learning outcomes obtained after the implementation of the actions of cycle I and cycle II have increased, because at the time of the implementation of the second cycle the learning outcomes of students have reached the completeness criteria of the study which is $85 \%$. In the first cycle it was not successful because the value obtained in the first cycle was only $68.85 \%$ because the teacher had not maximally implemented the steps of the Group Investigation learning model, besides the student activity in learning was still lacking, this happened because the teacher controlled students in learning yet the maximum is that most students in the class only play with group friends and expect each other's answers to be copied and there is no initiative to exchange opinions with each other. The group assignments given by the teacher cannot be resolved other than that while describing the results of the discussion the group members did not dare to be even embarrassed and hesitant to convey the results of the discussion. Then when the teacher gives an individual evaluation in the form of an assessment sheet some students do not answer some of the questions given by the teacher, so the learning results obtained are not maximal.

The learning outcomes of the second cycle were $88.84 \%$ where the value was $\geq 85 \%$ because the implementation of the Group Investigation learning model on learning outcomes in social sciences subjects about natural resources in Indonesia seemed to produce good results. Where in the process of learning activities students look so enthusiastic and motivated in learning. Students who had no will in learning eventually became enthusiastic in learning. This can be seen in the process of learning activities because when the teacher presents the material, the teacher begins to provoke activeness by means of researchers to be more active in creating an enjoyable learning process for students and prioritizing the activity of each student in receiving the material, such as research findings from Sumilat that the application of the Group Invetigation model can make students active and generate their social spirit through a process of discussion and work together to conduct investigations and dare to express opinions when presenting the results of their investigations [6].

From the description above, the Group Investigation model on social sciences learning improves the results of learning Natural Resources material. Based on the results of this study, it can be seen that if the teacher carries out his duties to the maximum in learning management it provides optimal student learning outcomes. This is according to what expressed by Tuerah where learning management influences teacher performance [7]. 
Journal of Educational Method and Technology Vol. 2 No. 1, April 2019

P-ISSN 2622-8459 E-ISSN 2622-8467

http://ejournal.unima.ac.id/index.php/jemtec

\section{Conclusion}

Based on the results of the research and discussion, it can be concluded that the use of the group investigation learning model can improve social sciences learning outcomes in natural resources material of fourth grade students of elementary school and the use of group investigation learning models in social sciences learning can motivate students and work together in groups

\section{References}

[1] Supriyono, 2003. Teori Belajar Pembelajaran. Remaja Rosdakarya: Bandung.

[2] Rusman, 2010. Model - Model Pembelajaran Mengembangkan Profesionalisme Guru. Jakarta: PT Raja Grafindo Persada

[3] Trianto, 2009. Model Pembelajaran Terpadu, Konsep, Strategi, dan Implementasi dalam Kurikulum Tingkat Satuan Pendidikan. Jakarta : Bumi Askara.

[4] Susanto Ahmad, 2014. Pengembangan Pembelajaran IPS Di Sekolah Dasar . Bandung : Prenadamedia Group

[5] Sumilat, J. M. (2018). Pemanfaatan Media Pembelajaran Matematika Interaktif Untuk Meningkatkan Hasil Belajar Siswa di SD Negeri 2 Tataaran. Jurnal Inventa, 2(1), 40-46.

[6] Sumilat. J. M, 2017. Penggunaan Model Pembelajaran Group Investigation Untuk Meningkatkan Hasil Belajar Matematika Materi Operasi Campuran Bilangan Bulat. Jurnal Forum Pendidikan. Vol.13 No 2, 55-64.

[7] Tuerah, R.M (2017, September). Analysis of Teacher Performance on Learning Managment In Primary School. In 9th International Conference For Science Educators and Teachers (ICSET 2017). Atlantis Press. 
Journal of Educational Method and Technology Vol. 2 No. 1, April 2019

P-ISSN 2622-8459 E-ISSN 2622-8467

http://ejournal.unima.ac.id/index.php/jemtec 